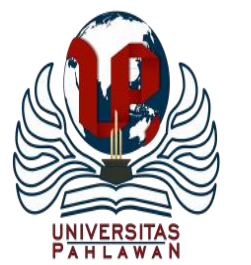

Edukatif : Jurnal Ilmu Pendidikan Volume 3 Nomor 5 Tahun 2021 Halm 2776 - 2787

EDUKATIF: JURNAL ILMU PENDIDIKAN

Research \& Learning in Education

https://edukatif.org/index.php/edukatif/index

\title{
Implementasi Supervisi Manajerial dalam Meningkatkan Mutu Pendidikan di Madrasah Ibtidaiyah
}

\author{
Tan Gusli ${ }^{1 凶}$, Sufyarma Marsidin ${ }^{2}$, Rifma $^{3}$ \\ Universitas Negeri Padang, Indonesia ${ }^{1,2,3}$

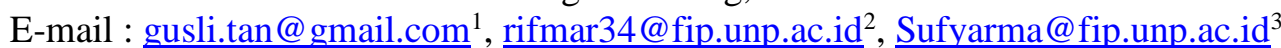

\begin{abstract}
Abstrak
Supervisi manajerial memiliki peran penting dalam peningkatan mutu pendidikan di Madrasah Ibtidaiyah. Penelitian ini bertujuan untuk melihat sasaran suvervisi manajerial; pelaksanaan supervisi manajerial dan peran pengawas dalam peningkatan mutu pendidikan. Penelitian dilaksanakan pada MIN 3 Kota Padang. Metode yang digunakan dalam penelitian adalah menggunakan pendekatan kualitatif. Prosedur pengumpulan data dilakukan melalui observasi, wawancara, dan studi dokumentasi. Hasil penelitian menunjukkan bahwa : 1). Sasaran supervisi manajerial yang telah dilaksanakan oleh pengawas pada madrasah Ibtidaiyah telah terpenuhi sesuai standar kompetensi pengawas yang tertera pada regulasi dan peraturan terkait dengan pengawas. 2). Pengawas dalam melakukan supervisi manajerial telah memperhatikan kompetensi kepala madrasah dalam mengelola manajerial. 3) Peran pengawas madrasah adalah sangat penting, tanpa adanya supervisi manajerial yang dilaksnakan oleh pengawas di madrasah ibtidaiyah maka madrasah tidak akan mampu mengembangkan madrasahnya. Pengawas bukan hanya sekedar seorang konsultas tetapi juga adalah sebagai motivator dalam rangka meningkatkan mutu pendidkan di madrasah ibtidaiyah.khususnya dan madrasah pada umumnya.
\end{abstract}

Kata Kunci: Implementasi, Supervisi Manajerial, Mutu Pendidikan.

\begin{abstract}
Managerial supervision has an important role in improving the quality of education in Madrasah Ibtidaiyah. This study aims to see the objectives of managerial supervision; implementation of managerial supervision and the role of supervisors in improving the quality of education. The research was conducted at MIN 3 Padang City. The method used in this research is using a qualitative approach. Data collection procedures were carried out through observation, interviews, and documentation studies. The results of the study show that: 1). The targets of managerial supervision that have been carried out by supervisors at Madrasah Ibtidaiyah have met the competency standards of supervisors stated in the regulations and regulations related to supervisors. 2). Supervisors in conducting managerial supervision have paid attention to the competence of the madrasah principal in managerial management. 2) The role of madrasa supervisors is very important, without managerial supervision carried out by supervisors at madrasah ibtidaiyah, madrasah will not be able to develop their madrasah. The supervisor is not just a consultant, he is a motivator in order to improve the quality of education at madrasah ibtidaiyah, in particular and madrasas in general.
\end{abstract}

Keywords: Implementation, Managerial Supervision, Quality of Education.

Copyright (c) 2021 Tan Gusli, Sufyarma Marsidin, Rifma

$\square$ Corresponding author

Email : gusli.tan@gmail.com

DOI : https://doi.org/10.31004/edukatif.v3i5.945

ISSN 2656-8063 (Media Cetak)

ISSN 2656-8071 (Media Online)

Edukatif : Jurnal Ilmu Pendidikan Vol 3 No 5 Tahun 2021 p-ISSN 2656-8063 e-ISSN 2656-8071 
2777 Implementasi Supervisi Manajerial dalam Meningkatkan Mutu Pendidikan di Madrasah Ibtidaiyah - Tan Gusli, Sufyarma Marsidin, Rifma

DOI: https://doi.org/10.31004/edukatif.v3i5.945

\section{PENDAHULUAN}

Pendidikan merupakan suatu usaha sadar yang dilakukan secara sistematis dalam mewujudkan suasana belajar-mengajar agar para peserta didik dapat mengembangkan potensi dirinya. Dengan adanya pendidikan maka seseorang dapat memiliki kecerdasan, akhlak mulia, kepribadian, kekuatan spiritual, dan keterampilan yang bermanfaat bagi diri sendiri dan masyarakat (M. Prawiro, 2018). Salah satu usaha yang dilakukan untuk mencapai tujuan pendidikan ialah melalui proses pembelajaran di sekolah atau Madrasah. Dalam usaha meningkatkan mutu pendidikan secara berkelanjutan di sekolah/Madrasah, memerlukan guru, kepala Madrasah dan pengawas profesional yang dapat menjalankan tugas, peran dan fungsi masing-masing. kepala Madrasah memiliki peran penting dalam pengelolaan kelembagaan secara efektif dan efisien, begitu juga pengawas Madrasah. Dalam konteks ini maka perlu adanya suversisi.

Supervisi adalah kegiatan yang dilakukan oleh pengawas satuan pendidikan dalam rangka membantu kepala sekolah atau Madrasah, guru dan tenaga kependidikan lainnya guna meningkatkan mutu dan efektivitas penyelenggaraan pendidikan dan pembelajaran. Supervisi ditujukan pada dua aspek yakni: manajerial dan akademik. Supervisi manajerial menitikberatkan pada pengamatan pada aspek-aspek pengelolaan dan administrasi sekolah yang berfungsi sebagai pendukung terlaksananya pembelajaran. Sementara supervisi akademik menitikberatkan pada pengamatan supervisor terhadap kegiatan akademik, berupa pembelajaran baik di dalam maupun di luar kelas.

Dalam Panduan Pelaksanaan Tugas Pengawas Sekolah/Madrasah (Direktorat Tenaga Kependidikan, 2009:20) dinyatakan bahwa supervisi manajerial adalah supervisi yang berkenaan dengan aspek pengelolaan sekolah yang terkait langsung dengan peningkatan efisiensi dan efektivitas sekolah yang mencakup perencanaan, koordinasi, pelaksanaan, penilaian, pengembangan kompetensi sumberdaya manusia (SDM) kependidikan dan sumberdaya lainnya (Kependidikan, 2009).

Salah satu faktor yang paling dominan dan berperan dalam mengantarkan keberhasilan madrasah dalarn prestasi akademik dan non akademik adalah faktor mutu Kepala Madrasah. Berkaitan dengan masalah tersebut, Supriadi menjelaskan bahwa "Erat hubungannya antara mutu Kepala Madrasah dengan berbagai aspek kehidupan Madrasah" (Supriadi; 1995:99). Pengembangan kemampuan profesional guru Madrasah Ibtidaiyah menjadi tanggung jawab Kepala Madrasah. Kepala Madrasah bertanggung jawab atas penyelenggaraan kegiatan pendidikan, administrasi Madrasah, pembinaan tenaga kependidikan lainnya dan pendayagunaan serta pemeliharaan sarana dan prasarana.

Peningkatan mutu pendidikan di madrasah juga ditentukan oleh pengawas madrasah. Dari hasil penelitian pembinaan guru melalui supervisi menunjukkan bahwa: "rata-rata kepala madrasah mengalami kesukaran dalam melakukan pembinaan terhadap guru melalui supervisi dengan teknik kunjungan kelas, menggunakan pertemuan pribadi, rapat dewan guru, menggunakan teknik kunjungan madrasah, pertemuan kelompok dan melalui penerbitan bulletin profesional" (Imran: 1995; 98-99). Adapun faktor faktor yang menyebabkan kesukaran kepala madrasah dalam melakukan supervisi meliputi: "terbatasnya kemampuan profesional, terbatasnya waktu, terbatasnya petunjuk pelaksanaan dan terbatasnya biaya” (Imran 1995:99).

Terkait dengan penelitian ini, berdasarkan informasi bahwa MIN 3 Kota Padang telah menerapkan supervisi manajerial yang dilaksanakan oleh pengawas secara konsisten minimal satu kali dalam sebulan dan telah terjadwal/ter scedule dengan baik.supervisi manajerial yang dilakukakn oleh pengawas madrasah jauh dari kesan kaku dan menakutkan tetapi sebaliknya supervisi manajerial yang dilaksanakan tepatnya merupakan pembinaan dan pendampingan dalam rangka meningkatkan mutu pendidikan di Madrasah Ibtidaiya. Kerjasama Kepala Madrasah dengan tenaga pendidik dan kependidikan serta masyarakat telah menjadikan madrasah ini menjadi madrasah memiliki capaian prestasi dan capaian terhadap delapan standar pendidikan. 
2778 Implementasi Supervisi Manajerial dalam Meningkatkan Mutu Pendidikan di Madrasah Ibtidaiyah - Tan Gusli, Sufyarma Marsidin, Rifma

DOI: https://doi.org/10.31004/edukatif.v3i5.945

Berangkat dari hal ini maka penulis ingin melihat apakah sasaran suvervisi manajerial telah terpenuhi; dan bagaimana pelaksanaan supervisi manajerial dan peran pengawas dalam peningkatan mutu pendidikan di Madrasah Ibtidaiyah.

\section{METODE PENELITIAN}

Penelitian ini menggunakan metode kualitatif deskriftif. berdasarkan fokus penelitian, peneliti memanfaatkan key Informan yang dipilih oleh peneliti yakni:(1) Kepala MIN 3 Kota Padang; (2) Wakil Kepala bidang Kurikulum; (3) Perwakilan Guru dan tenaga kependidikan (4) Pengawas Manajerial Madrasah khusus membina dan mengawasi MIN 3 Kota Padang. Kriteria peneliti dalam memilih informan tersebut dilihat dari peran, pengalaman, dan masa jabatan yang tergolong senior sehingga dapat memaparkan informasi dengan jelas sesuai kenyataan dan realitasnya dengan topik dan kajian informasi. Penelitian ini menggunakan teknik-teknik dalam rangka pengumpulan data di lapangan diantaranya: (1) teknik observasi berupa pengamatan dan pencatatan secara sistematik terhadap gejala yang tampak pada objek penelitian. Observasi yang dilakukan peneliti dengan mengamati prosedur pembinaan, pendampingan dan penilaian mengenai implementasi suvervisi manajeria di MIN 3 Kota Padang (2) teknik wawancara, merupakan teknik percakapan yang dilakukan oleh kedua belah pihak melibatkan peneliti sebagai pewawancara (interviewer) dan subyek atau responden sebagai terwawancara (interviewee). Wawancara yang digunakan peneliti adalah wawancara semi terstruktur, peneliti tetap menggunakan pedoman atau instrumen wawancara yang telah dibuat, namun tidak menutup kemungkinan peneliti dapat menanyakan semua hal yang tersirat dari penjelasan informan secara spontan yang tidak terdapat dalam pedoman wawancara; (3) Studi literatur dan dokumentasi, dikumpulkan setelah peneliti melakukan pengamatan data dan setelah melakukan wawancara kepada informan-informan terkait dengan supervisi manajerial di Madrasah. Hasil dari dokumentasi akan dijadikan sebagai bukti dari hasil wawancara maupun hasil observasi, sehingga data yang diperoleh terjamin kebenarannya.

\section{HASIL DAN PEMBAHASAN PENELITIAN}

\section{Pengertian Supervisi Manajerial}

Supervisi berasal dari kata super dan vision. Super berarti peringkat atau posisi yang lebih tinggi, Sedangkan kata vision mengandung makna kemampuan untuk menyadari sesuatu tidak benar-benar terlihat (Aedi, 2014). Supervisi berarti pandangan dari orang yang lebih ahli kepada orang yang memiliki keahlian di bawahnya. Orangnya disebut Supervisor atau istilah bagi orang yang melakukan supervisi yaitu seorang yang profesional ketika menjalankan tugasnya, bertindak atas dasar kaidah ilmiah untuk meningkatkan mutu pendidikan.

Dalam Carter Good's Dictionary education, dinyatakan bahwa supervisi adalah segala usaha pejabat sekolah dalam memimpin guru-guru dan tenaga kependidikan lainnya untuk memperbaiki pengajaran. Termasuk di dalamnya adalah menstimulasi, menyeleksi pertumbuhan dan perkembangan jabatan guru-guru, menyeleksi dan merevisi tujuan-tujuan pendidikan, bahan pengajaran, dan metode-metode mengajar serta mengevaluasi pengajaran (E. Mulyasa, 2011).

Berdasarkan pengertian diatas, maka supervisi merupakan kegiatan yang dilakukan oleh pengawas satuan pendidikan dalam rangka membantu kepala sekolah atau Madrasah, guru dan tenaga kependidikan lainnya guna meningkatkan mutu dan efektivitas penyelenggaraan pendidikan dan pembelajaran. Supervisi ditujukan pada dua aspek yakni: manajerial dan akademik. Supervisi manajerial ini menitikberatkan pada pengamatan pada aspek-aspek pengelolaan dan administrasi sekolah yang berfungsi sebagai pendukung 
2779 Implementasi Supervisi Manajerial dalam Meningkatkan Mutu Pendidikan di Madrasah Ibtidaiyah - Tan Gusli, Sufyarma Marsidin, Rifma

DOI: https://doi.org/10.31004/edukatif.v3i5.945

(supporting) terlaksananya pembelajaran. Sementara supervisi akademik menitikberatkan pada pengamatan supervisor terhadap kegiatan akademik, berupa pembelajaran baik di dalam maupun di luar kelas.

Pengawas sekolah atau madrasah dalam melaksanakan tugas dan fungsi supervisi manajerialnya berperan sebagai: pertama, sebagai kolaborator dan negosiator dalam proses perencanaan, koordinasi, pengembangan manajemen sekolah atau Madrasah, kedua, sebagai asesor dalam mengidentifikasi kelemahan dan menganalisis potensi sekolah atau Madrasah, ketiga, sebagai pusat informasi pengembangan mutu sekolah, dan keempat, sebagai evaluator terhadap pemaknaan hasil pengawasan. Dalam melakukan supervisi, pengawas sekaligus juga dituntut melakukan pematauan terhadap pelaksanaan standar nasional pendidikan yang meliputi delapan komponen, yaitu: (a) standar isi, (b) standar kompetensi lulusan, (c) standar proses, (d) tandar pendidik dan tenaga kependidikan, (e) standar sarana dan prasarana, (f) standar pengelolaan, (g) standar pembiayaan, dan (h) standar penilaian. Tujuan supervisi terhadap kedelapan aspek tersebut adalah agar sekolah terakreditasi dengan baik dan dapat memenuhi standar nasional pendidikan.

Salah satu fokus penting lainnya dalam dalam supervisi manajerial oleh pengawas terhadap madrasah, adalah berkaitan pengelolaan atau manajemen madrasah (Elfira, 2017). Berikut adalah ruang lingkup supervise manajerial: 1) Pemantauan, pada manajemen perubahan pemantauan mengarah pada pencapaian delapan Standar Nasional Pendidikan (SNP) dan memanfaatkan hasil-hasilnya untuk membantu kepala madrasah mempersiapkan akreditasi madrasah, 2) Penilaian. Penilaian ini terhadap kinerja kepala madrasah dalam hal menjadi agen perubahan pertama di madrasah dalam implementasi kurikulum 2013 sesuai dengan standar nasional pendidikan, 3) Pembinaan. Hasil pemantauan dan penilaian oleh pengawas harus dijadikan dasar untuk peningkatan kompetensi dan profesionalisme kepala madrasah dan ditindaklanjuti dengan melakukan pembinaan baik berupa pembimbingan dan/ atau pelatihan kepala madrasah.

Pada implementasi kurikulum 2013 supervisi manajerial sangat dibutuhkan mengingat adanya perubahan mindset dan perilaku warga madrasah yang dipimpin oleh kepala madrasah.Karena itu pengawas harus melakukan pendampingan kepada kepala madrasah agar mendapat kepastian bahwa implementasi kurikulum berjalan sesuai dengan harapan.

\section{Prinsip Supervisi Manajerial}

Prinsip-prinsip supervisi manajerial pada hakikatnya tidak berbeda dengan supervisi akademik, yaitu: 1) Prinsip yang pertama dan utama dalam supervisi adalah kepala madrasah harus menjauhkan diri dari sifat otoriter, di mana ia bertindak sebagai atasan dan kepala madrasah/guru sebagai bawahan, 2) Supervisi harus mampu menciptakan hubungan kemanusiaan yang harmonis. Hubungan kemanusiaan yang harus diciptakan harus bersifat terbuka, kesetiakawanan, dan informal, 3) Supervisi harus dilakukan secara berkesinambungan. Supervisi bukan tugas bersifat sambilan yang hanya dilakukan sewaktu-waktu jika ada kesempatan, 4) Supervisi harus demokratis. Supervisor tidak boleh mendominasi pelaksanaan supervisi. Titik tekan supervisi yang demokratis adalah aktif dan kooperatif, 5) Program supervisi harus integral. Di dalam setiap organisasi pendidikan terdapat bermacam-macam sistem perilaku dengan tujuan sama, yaitu tujuan pendidikan, 6) Supervisi harus komprehensif. Program supervisi harus mencakup keseluruhan aspek, karena hakikatnya suatu aspek pasti terkait dengan aspek lainnya.

Supervisi harus konstruktif. Supervisi bukanlah sekali untuk mencari kesalahan-kesalahan guru. Supervisi harus obyektif. Dalam menyusun,melaksanakan, dan mengevaluasi, keberhasilan program supervisi harus obyektif. Objektivitas dalam penyusunan program berarti bahwa program supervisi itu harus disusun berdasarkan persoalan dan kebutuhan nyata yang dihadapi madrasah. 
2780 Implementasi Supervisi Manajerial dalam Meningkatkan Mutu Pendidikan di Madrasah Ibtidaiyah - Tan Gusli, Sufyarma Marsidin, Rifma

DOI: https://doi.org/10.31004/edukatif.v3i5.945

\section{Metode Supervisi Manajerial}

Monitoring dan Evaluasi. Monitoring adalah model kegiatan pemantauan penyelenggaraan madrasah, apakah sudah sesuai dengan rencana, program, dan/atau standar yang telah ditetapkan, serta menemukan hambatan-hambatan yang harus diatasi dalam pelaksanaan program. Kegiatan monitoring bertujuan untuk menetapkan standar untuk mengukur prestasi, mengukur prestasi, menganalisis apakah prestasi memenuhi standar, dan mengambil tindakan apabila prestasi kurang/tidak memenuhi standar. Sasaran utama monitoring adalah untuk menghimpun informasi melalui pemotretan kondisi nyata madrasah sehingga data yang diperoleh dapat digunakan untuk bahan pengambilan keputusan perbaikan mutu. Evaluasi adalah proses untuk menghimpun informasi mengenai peta proses dan progress penyelenggaraan madrasah dibandingkan dengan target yang direncanakan sehinga dapat diketahui peta keberhasilan dalam kurun waktu tertentu. Tujuan evaluasi utamanya adalah untuk mengetahui tingkat keterlaksanaan program, mengetahui keberhasilan program, mendapatkan bahan/masukan dalam perencanaan tahun berikutnya, dan memberikan penilaian (judgement) terhadap madrasah.

Refleksi dan Diskusi Kelompok. Prinsip utama manajemen madrasah adalah mengerahkan sumber daya dan meningkatkan partisipasi. Dalam strategi ini pengawas perlu menyampaikan hasil monitoring secara terbuka kepada pihak madrasah, terutama kepala madrasah, wakil kepala madrasah, komite madrasah dan guru. Madrasah selanjutnya merefleksi data yang pengawas sampaikan sehingga pihak madrasah menemukan sendiri faktor-faktor penghambat serta pendukung mereka hadapi. Diskusi kelompok ini merupakan bagian dari usaha menyatukan pandangan stakeholder mengenai realitas kondisi (kekuatan dan kelemahan) madrasah, serta menentukan langkah-langkah strategis maupun operasional untuk melakukan perbaikan mutu berkelanjutan.

Metode Delphi dapat digunakan oleh pengawas dalam membantu pihak madrasah merumuskan visi, misi dan tujuannya. Sesuai dengan konsep MBS, dalam merumuskan Rencana Pengembangan Madrasah.Metode Delphi menurut Gorton adalah sebagai berikut: a) Mengidentifikasi individu atau pihakpihak yang dianggap memahami persoalan dan hendak dimintai pendapatnya mengenai pengembangan madrasah; b) Masing-masing pihak diminta mengajukan pendapatnya secara tertulis tanpa disertai nama/identitas; c) Mengumpulkan pendapat yang masuk, dan membuat daftar urutannya sesuai dengan jumlah orang yang berpendapat sama, d) Menyampaikan kembali daftar rumusan pendapat dari berbagai pihak tersebut untuk diberikan urutan prioritasnya, e) Mengumpulkan kembali urutan prioritas menurut peserta, dan menyampaikan hasil akhir prioritas keputusan dari seluruh peserta yang dimintai pendapatnya.

Metode Delphi merupakan cara yang efisien untuk melibatkan banyak stakeholder madrasah tanpa memandang faktor-faktor status yang sering menjadi kendala dalam sebuah diskusi atau musyawarah dengan target agar semua yang hadir dalam musyawarah mengungkapkan gagasan. Hal ini merupakan solusi dari masalah seringnya pertemuan didominasi oleh orang-orang tertentu.

Workshop atau lokakarya merupakan salah satu metode yang dapat pengawas lakukan dalam melaksankan supervisi manajerial. Strategi ini untuk mendorong dinamika kelompok dan dapat melibatkan beberapa kepala madrasah, wakil kepala madrasah dan/atau perwakilan komite madrasah. Penyelenggaraan workshop ini tentu disesuaikan dengan tujuan yang hendak dicapai. Yang penting seorang pengawas memiliki kewajiban untuk mengarahkan workshop sekurang-kurangnya 3 kali dalam setahun.

\section{Kompetensi Manajerial}

Kompetensi manajerial terdiri atas 1) Menguasai metode, teknik dan prinsip-prinsip supervisi dalam rangka meningkatkan mutu pendidikan, 2) Menyusun program kepengawasan berdasarkan visi misi tujuan dan program-program madrasah binaannya, 3) Menyusun metode kerja dan berbagai instrumen yang diperlukan 
untuk melaksanakan tugas pokok dan fungsi pengawasan, 4) Membina kepala madrasah dalam mengelola satuan pendidikan berdasarkan manajemen peningkatan mutu berbasisi madrasah (MPMBS), 5) Membina kepala madrasah dalam dalam melaksanakan administrasi satuan pendidikan meliputi administrasi kesisiwaan, kurikulum dan pembelajaran, pendidik dan tenaga kependidikan, sarana dan prasarana, pembiayaan, keuangan, lingkungan madrasah dan peran setrta masyarakat, 6) Membantu madrasah dalam menyusun indikator keberhasilan mutu pendidikan di madrasah, 7) Membina staf madrasah dalam melaksanakan tugas pokok dan tanggung jawabnya, 8) Memotivasi pengembangan karir kepala madrasah, guru dan tenaga kependidikan lainnya sesuai dengan peraturan dan ketentuan yang berlaku, 9) Menyusun laporan hasil-hasil pengawasan pada madrasah-madrasah binaannya dan menindak lanjutinya untuk perbaikan mutu pendidikan dan progran pengawasan berikutnya, 10) Mendorong guru dan kepala madrasah untuk menemukan kelebihan dan kekurangan dalam melaksanakan tugas pokoknya, 11) Menjelaskan berbagai inovasi dan kebijakan pendidikan kepada guru dan kepala madrasah, 12) Memantau pelaksanaan inovasi dan kebijakan pendidikan pada madrasah-madrasah binaannya.

\section{Mutu Pendidikan di Madrasah}

Salah satu menjadi indikator keberhasilan seorang kepala Madrasah diukur dari mutu pendidikan yang ada di Madrasah yang dipimpinnya. Dalam konteks pendidikan, mutu mencakup input, proses, dan output pendidikan (Depdiknas, 2009). Input pendidikan merupakan segala sesuatu yang harus tersedia karena dibutuhkan untuk berlangsungnya proses. Proses pendidikan merupakan berubahnya sesuatu menjadi sesuatu yang lain dengan mengintegrasikan input Madrasah sehingga mampu mewujudkan situasi pembelajaran yang menyenangkan, motivasi dan minat belajar yang tinggi. Output pendidikan merupakan kinerja sekolah yang dapat diukur dari kualitasnya, produktivitasnya, efisiensinya, inovasinya, dan moral kerjanya. Dalam konsep yang lebih luas, mutu pendidikan mempunyai makna sebagai suatu kadar proses dan hasil pendidikan secara keseluruhan yang ditetapkan sesuai dengan pendekatan dan kriteria tertentu (Dharma, 2002).

Mutu pendidikan pada madrasah ditentukan oleh ketiga unsur di atas, yaitu kualitas input, kualitas proses, dan kualitas output dan outcome. Kualitas input pendidikan mempengaruhi kualitas proses pendidikan, kualitas proses pendidikan mempengaruhi kualitas output dan outcome pendidikan. Antara ketiganya selalu ada keterkaitan dan saling mempengaruhi. Manajemen peningkatan mutu madrasah memiliki karakteristik yang perlu dipahami oleh madrasah yang akan menerapkannya. Dalam bahasa lain, jika madrasah ingin sukses dalam menerapkannya maka sejumlah karakteristik perlu dimiliki oleh madrasah, yaitu karakteristik dari madrasah yang efektif, manajemen peningkatan mutu madrasah merupakan wadah, maka madrasah efektif adalah isinya (Fatah Syukur, 2011).

\section{Implementasi Supervisi Manajerial Dalam Meningkatkan Mutu Pendidikan Di Madrasah Ibtidaiyah Sasaran Suvervisi Manajerial di Madrasah Ibtidaiyah}

Peningkatan Mutu Pendidikan di Madrasah Ibtidaiyah tidak akan dapat tercapai dengan baik tanpa adanya partisipasi lansung dari seluruh elemen madrasah, partisipasi warga madrasah dan adanya pendampingan dan supervisi manajerial yang dilakukan oleh pengawas Madrasah. Supervisi memiliki sasaran agar manajemen Madrasah menjadi lebih terarah dan terpantau sesuai dengan regulasi dan perundang undangan manajemen pendidikan. Sasaran supervisi manajerial adalah terkait dengan aspek pengelolaan dan aspek administrasi yang mendukung terhadap pelaksanaan proses pembelajaran.

Sasaran supervisi manajerial adalah dalam meningkatkan manajemen Madrasah melalui peningkatan kemampuan administratif tenaga kependidikan atau sumberdaya Madrasah lainnya dalam melaksanakan tugas dan kewajiban yang mendukung terlaksananya proses pembelajaran dan peningkatan mutu di Madrasah. Hal ini dilakukan setiap pengawas ketika melakukan supervisi manajerial pada sekolah binaannya. Sasaran supervisi manajerial yang ditemukan sesuai dengan pendapat Sudrajat (2015: 21) bahwa "sasaran supervisi 


\section{Implementasi Supervisi Manajerial dalam Meningkatkan Mutu Pendidikan di Madrasah Ibtidaiyah - Tan}

Gusli, Sufyarma Marsidin, Rifma

DOI: https://doi.org/10.31004/edukatif.v3i5.945

manajerial adalah membantu kepala sekolah dan staf sekolah lainnya dalam mengelola administrasi pendidikan. Hal ini berdasarkan dengan pernyataan pengawas Madrasah bahwa sasaran supervisi adalah Kepala Madarasah selaku manajer Madarasah tersebut". Kepala madrasah diwawancarai tim pengawas terkait dengan pengelolaan Madrasah, pengelolaan administrasi Madrasah dan inovasi Kepala Madrasah dalam memimpin Madrasah. Adapu inovasi tersebut meliputi manajemen peserta didik, manajemen sumber daya manusia, manajemen kurikulum, manajemen sarana dan prasarana, dan manajemen keuangan Madrasah.

Sasaran supervisi manajerial yang dilaksanakan pengawas melihat sejauhmana kepala madrasah untuk melakukan pembinaan dan memantau kesesuaian antara perencanaan dan kegiatan yang telah dilaksanakan, dengan tujuan untuk melakukan perbaikan-perbaikan mutu di masa yang akan datang. Metode yang dilakukan pengawas sekolah adalah mewawancarai kepala Madrasah terkait dengan delapan Standar Nasional Pendidikan yang telah tercapai, penelaahan dokumen administratif Madrasah. Inovasinya dalam memimpin Madrasah, dan capaian lima substansi manajemen pendidikan yang meliputi manajemen peserta didik, manajemen sumber daya manusia, manajemen kurikulum, manajemen sarana dan prasarana, dan manajemen keuangan sekolah. Adapun capaian tersebut:

Pertama, Dalam manajemen peserta didik, setiap tahunnya penerimaan siswa baru di Madrasah dilaksanakan secara serentak bersama dengan madrasah. Penerimaan siswa dilaksanakan pada waktu Penerimaan Peserta Didik Baru (PPDB). Karakteristik, bakat, minat siswa yang memiliki perbedaan perlu diketahui oleh pihak Madrasah. Dan hal ini diperlukan untuk mengembangan potensi siswa. Selain dari kegiatan kurikuler yang dilaksanakan rutin setiap hari, pengembangan potensi, minat dan bakat siswa juga dapat disalurkan melalui kegiatan ekstra kurikuler yang selalu dilaksanakan setiap minggunya di luar proses belajar dan mengajar. Kegiatan ekstra kurikuler yang dilaksnakan di antaranya adalah Pramuka, Paskibra, Tahfiz, Sain center, pidato, drum band, tari, dan lain-lain yang kesemuanya itu dikelola dengan baik oleh kepala madrasah yang dibantu oleh wakil kepala madrasah bagian kesiswaan. Disamping itu faktor-faktor lain di luar individu siswa juga harus diketahui oleh pihak madrasah agar faktor tersebut dapat mendukung siswa dalam pendidikan, bukan sebaliknya sebagai bumerang siswa dalam menuntut ilmu di madrasah.

Kedua, Peranan Sumber Daya Manusia dalam pengelolaan manajemen madrasah sangat penting. Adapun manfaat pengelolaan sumber daya manusia kependidikan, bahwa pengelolaan sumber daya manusia dipandang sangat penting, sebagai pelaksana pendidikan, sumber daya manusia sudah terampil tahu akan kewajibannya, memahami apa yang dilakukan, semuanya akan berjalan dengan baik, sehingga akan mengarah kepada terwujudnya apa yang menjadi tujuan Madrasah. Dalam hal ini yang terlibat dalam pengelolaan Sumber daya manusia di Madrasah adalah kepala madrasah yang dibantu oleh wakil kepala madrasah, yaitu wakil kurikulum, wakil kesiswaan dan wakil sapras dan staff pada tata usaha. Disamping itu Kepala Madrasah bekerjasama dengan komite madrasah dan secara berkala pihak komite berkunjung dan membahasa program yang mendukung kemajuan Madrasah.

Ketiga, Manajemen Kurikulum dikembangkan sebagai pedoman penyelenggaraan kegiatan pembelajaran untuk mencapai tujuan pendidikan nasional. Tujuan ini meliputi tujuan pendidikan nasional, tujuan pendidikan dasar, dan tujuan yang disesuaikan dengan kekhasan, kondisi dan potensi daerah dan peserta didik. Oleh sebab itu, kurikulum yang disusun, memungkinkan penyesuaian program pendidikan dengan kebutuhan dan potensi yang ada di daerah tempat Madrasah berada. Bentuk pengembangannya seperti materi, tentang kedalam materi, ketuntasan belajar. Dalam administrasinya kurikulum dikembangkan dalam bentuk silabus, Rencana Pembelajaran, peranglat evaluasi dan perangkat pengembangannya, waktu penyusunan kurikulum dilaksanakan diakhir semester.

Keempat, dalam manajemen Keuangan, sumber dana yang berasal dari DIPA dan Bantuan Operasional Madrasah (BOS) untuk kegiatan madrasah. Sementara untuk gaji guru pegawai diperoleh dari APBN. Dalam pengelolaan keuangan, madrasah selalu menyusun RAPBS setiap tahun pelajaran bersama pihak guru dan komite, apalagi dengan adanya BOS pihak madrasah harus menyusun RAPBS setiap semester. Manfaat dari 


\section{Implementasi Supervisi Manajerial dalam Meningkatkan Mutu Pendidikan di Madrasah Ibtidaiyah - Tan Gusli, Sufyarma Marsidin, Rifma}

DOI: https://doi.org/10.31004/edukatif.v3i5.945

penyusunan RAPBS, madrasah sudah pasti memerlukan biaya, tentunya perlu memperhitungkan uang masuk dan uang keluarnya dengan penyusunan relatif, uang ini tidak meyimpang, dengan skala prioritas. Perencanaan, pelaksanaan dan pengawasan anggaran pendapatan dan belanja tahunan meliputi: 1) Sumber pemasukan, pengeluaran, dan jumlah dana yang dikelola, 2) Penyusunan dan pencairan anggaran, serta penggalangan dana di luar dana investasi dan operasional, 3) Kewenangan dan tanggung jawab kepala madrasah dalam membelanjakan anggaran pendidikan sesuai dengan peruntukannya, 4) Pembukuan semua penerimaan dan pengeluaran serta penggunaan anggaran untuk dilaporkan kepada komiite madrasah serta institusi di atasnya, mengacu kepada ketentuan Standar Biaya dan Standar Biaya Kementrian Keuangan. Rencana kegiatan dan anggaran madrasah merupakan kegiatan yang dilakukan madrasah selama satu tahun.

Kelima, Pelaksanaan Program Sarana dan Prasarana, telah menerapkan system manajemen yang meliputi, perencanaan, pengadaan, penyimpanan, pemeliharaan, inventarisasi, penghapusan dan pengawasan yaitu: 1) Perencanaan dengan adanya analisis materi, Menunjuk seseorang yang akan diserahkan, mencari atau menetapkan dana, menseleksi alat, 2) Pengadaan dengan Membuat daftar perencanaan pengadaan, Menyusun daftar perkiraan biaya, Menetapkan segala prioritas pengadaannya, 3) Penyimpanan dan pemeliharaan adalah aktivitas yang harus dijalankan untuk menjaga perlengkapan dalam kondisi siap pakai, 4) Inventarisasi, melakukan pencatatan sarana dan prasarana, 5) Penghapusan barang apabila perlengkapan yang rusak dan tidak bisa diperbaiki lagi, 6) Pengawasan sarana dan prasarana dilakukan dengan cara meminta data-data dan laporan dari waka sarana dan prasarana.

Keenam, Pelaksanaan Kerjasama Madrasah dan masyarakat berjalan dengan baikdengan melibatkan seluruh stakeholder dan juga alumni Madrasah serta komite Madrasah. Selain bekerja sama dengan masyarakat atau komite juga bekerja sama dengan Pemerintahan dan Pihak Swasta. Kerjasama sekolah dengan masyarakat yaitu dengan komite, masyarakat dan wali diakomodasi di Komite madrasah dan setiap akhir semester mengadakan rapat wali murid. Selain itu, madrasah juga bekerja sama dengan pemerintah dan pihak swasta, misalnya dalam hal keamanan dan kebersihan lingkungan di sekitar madrasah.

Hasil penelitian mengenai supervisi manajerial adalah kegiatan yang dilaksanakan secara rutin tersebut memiliki fungsi pembinaan, dimana fungsi tersebut dipergunakan pengawas untuk melakukan koordinasi dengan kepala Madrasah dan guru-guru yang bersangkutan lewat pertemuan atau rapat. Rapat tersebut membahas mengenai informasi-informasi terkini, kebijakan dinas, dan penguatan-penguatan materi. Pada dasarnya, supervisi manajerial adalah usaha pemberian bantuan yang diberikan oleh pengawas kepada pendidik dan tenaga kependidikan dalam rangka pembinaan, penilaian dan bimbingan mulai dari rencana program, proses, sampai dengan evaluasi, hasil dan laporan kegiatan. Maka, fungsi yang ditemukan sejauh ini adalah untuk melihat kesesuaian antara rencana, pelaksanaan, evaluasi dengan Rencana Tindak Lanjut yang dilakukan oleh Madrasah. Secara umum, pengawas melihat program madrasah yang diajukan, pelaksanaan kegiatan, dokumen kegiatan seperti apa, dan evaluasi kegiatan. Setelah dokumen kegiatan selesai dievaluasi oleh pengawas, maka pengawas akan memberikan rekomendasi tindak lanjut. Rekomendasi ini digunakan sebagai langkah untuk mengembangkan manajerial Madrasah agar kedepannya mampu memperbaiki diri. Berdasarkan hal tersebut, supervisi bukan hanya sebagai alat ukur apakah program telah sesuai dengan pelaksanaannya. Akan tetapi, supervisi manajerial sebagai kegiatan pengawasan dibidang personil pelaksana dan manajemen Madrasah yang menjalankan pengadministrasian Madrasah dalam rangka meningkatkan kualitas proses pembelajaran.

Sasaran supervisi manajerial yang telah dilaksanakan pada madrasah Ibtidaiyah tersebut tersebut telah terpenuhi oleh karena kompetensi pengawas manajerial yang tertera pada Permendiknas No. 12 Tahun 2017 tentang kompetensi supervisi manajerial poin ke lima yang berbunyi "Membina kepala sekolah dalam pengelolaan dan administrasi satuan pendidikan berdasarkan manajemen peningkatan mutu pendidikan di sekolah atau madrasah". Hal inilah yang menentukan berhasil tidaknya pengawas dalam melakukan pembinaan kepala Madrasah dan manajemen pendidikan Madrasah yang relevan dengan peraturan tersebut, 
2784 Implementasi Supervisi Manajerial dalam Meningkatkan Mutu Pendidikan di Madrasah Ibtidaiyah - Tan Gusli, Sufyarma Marsidin, Rifma

DOI: https://doi.org/10.31004/edukatif.v3i5.945

maka kompetensi tiap-tiap pengawas sangat berpengaruh dengan capaian mutu pendidikan di madrasah binaan.

Dari uraian tersebut diatas dapat dikatakan bahwa supervisi manajerial tersebut sebagai upaya Madrasah dalam meminimalisir kendala dalam pelaksanaan program kerja Madrasah agar pelaksanaan kegiatan berjalan sebagai mana mestinya sebab supervisi manajerial dimaksudkan sebagai kegiatan pembinaan yang fokusnya aspek-aspek Manajemen madrasah. Fungsi tersebut tidak akan tercapai tanpa adanya kerjasama antara pengawas dan Kepala madrasah selaku manajer pendidikan. Supervisi manajerial yang dilaksanakan oleh pengawas harus dilakukan secara intens. intensitas pelaksanaan supervisi manajerial yang dilakukan pengawas akan sangat berpengaruh terhadap peningkatan kualitas pembelajaran yang akan meningkatkan Mutu pendidikan di Madrasah Ibtidaiyah.

\section{Pelaksanaan Supervisi Manajerial di Madrasah}

Hasil penelitian menunjukkan bahwa pelaksanaan supervisi manajerial terhadap madrasah ibtidaiyah telah memiliki program yang telah disusun secara bersama oleh kelompok kerja pengawas (Pokjawas) yang dirumuskan dalam rapat kerja pengawas. Rapat kerja pengawas ini dilakukan untuk menghasilkan program kerja dalam rangka pemenuhan salah satu kewajiban dan tanggung jawab pengawas dalam melaksanakan tugas fungsionalnya. Hal ini sesuai ketentuan peraturan yang ditetapkan, yaitu PERMENPAN No. 21 tahun 2010, Pasal III, tentang Kewajiban, Tanggung-jawab dan Wewenang, butir (a), yang menyatakan bahwa: .pengawas dalam melaksanakan tugas adalah menyusun program pengawasan, melaksanakan program pengawasan, melaksankan evaluasi hasil pelaksanaan pengawasan, membimbing dan melatih para pendidik dan tenaga kependidikan.

Pelaksanaan supervisi manajerial oleh pengawas terhadap pelaksanaan tugas Kepala Madrasah dan semua personil di madrasah untuk mencapai tujuan yang sudah ditetapkan. Secara umum pengawas dalam melaksanakan supervisi manajerial pada madrasah Ibtidaiyah telah menempuh langkah yang efektif yaitu dengan melakukan kegiatan pra supervisi melalui koordinasi dan sosialisasi tentang rencana kegiatan supervisi sehingga hal ini dipandang dapat mewujudkan komunikasi yang baik dari pengawas ke pengelola madrasah atau sebaliknya. Dengan melakukan pra supervisi ini diharapkan dapat membantu pengawas dan pengelola madrasah dalam tercapai tujuan pelaksanaan supervisi managerial. esensi dari pelaksanaan supervisi adalah kegiatan pemantauan, pembinaan dan pengawasan terhadap kepala sekolah dan seluruh elemen sekolah lainnya di dalam mengelola, mengadministrasikan dan melaksanakan seluruh aktivitas sekolah sehingga dapat berjalan dengan efektif dan efesien dalam rangka mencapai tujuan sekolah serta memenuhi Standar Nasional Pendidikan (Aedi, 2014 : 193).

Berdasarkan hal di atas, dari hasil penelitian dapat dikatakan tahapan supervisi managerial yang telah dilaksanakan pengawas pada madrasah ibtidaiyah, secara umum telah berjalan secara efektif dan efesien. Dari informasi yang diperoleh bahwa madrasah ibtidaiyah telah mendapatkan pembinaan supervisi manajerial dari pengawas dan secara umum sudah mengalami peningkatan dalam fungsi pengeloaan administrasi madrasah, sesuai dengan observasi lapangan yang peneliti lakukan bahwa madrasah ibtidaiyah yang diteliti, menunjukkan ada kemajuan dari segi pemenuhan dan pelaksnaan administrasi madrasah.

Kemajuan pada madrasah ibtidaiyah dalam pengelolaan sebgai berikut: 1) Madrasah telah memiliki rencana kerja sekolah dalam bentuk dokumen, 2). Penataan administrasi dilakukan dengan tertib, telah terkomputerisasi, DUK dipajang di ruang adminsitrasi, begitupula dengan administrasi kesiswaan terdata dan teratur. 3) madrasah telah mempublikasikan visi, misi dan tujuan sekolah, struktur organisasi, dan beberapa program lainnya dalam bentuk famplet dan dipasang di dinding. 4) Pengeloaan proses pembelajaran baik, terlihat dari pembagian tugas guru mengajar terarah pada potensi masing-masing guru atau staf. 5) madrasah mengisi buku induk siswa, memiliki inventaris barang, adanya buku tamu, adanya papan pengumu-man dan 


\section{Implementasi Supervisi Manajerial dalam Meningkatkan Mutu Pendidikan di Madrasah Ibtidaiyah - Tan}

Gusli, Sufyarma Marsidin, Rifma

DOI: https://doi.org/10.31004/edukatif.v3i5.945

mading sekolah 6) madrasah menyediakan alat-alat kebersihan dan ada petugas kebersihan. 7) madrasah mendapat dukungan dari orang tua yang tergabung dalam komite sekolah.

Dari hasil penelitian pengawas dalam melaksanakan supervisi manajerial telah membuat schedule/jadwal. Pengawas madrasah mengunjungi Madrasah secara ruti minimal dalam sebulan satu kali kunjungan. Seperti apa yang disampaikan oleh Kepala Madrasah Ibtidaiyah Negeri 3 Padang: "Kunjungan pengawan ke Madrasah dalam rangka supervisi minimal satu kali dalam sebualan dan itu telah terjadual dengan baik". Pengawas datang ke madrasah, dengan membawa instrumen untuk keperluan memperoleh data. pengawas akan meminta pihak madrasah untuk menunjukkan data dan dokumen yang terkait dengan penilaian, misalnya penilaian atau monitoring standar proses pembelajaran, dan ntuk memperoleh data pengawas melakukan wawancara kepada subjek atau kepala madrasah sesuai dengan kepentingan penilaian dan monitoring. Adanya kegiatan tersebut membantu pengawas memantau dan mengontrol kinerja Kepala madrasah, guru, staf, dan tenaga kependidikan dan dapat membuat rekomendasi program kegiatan di masa yang akan datang yang menentukan kemajuan tingkat kualitas pendidikan di madrasah.

Dari uraian diatas disimpulkan bahwa pelaksanaan supervisi manajerial dimadrasah ibtidaiyah telah berjalan dengan efektif dan terscedule dengan baik dan telah membawa perubahan pada pengelolaan dan administrasi madrasah ibtidaiyah yang diteliti.

\section{Peran Pengawas Manajerial dalam rangka meningkat Mutu Pendidikan di MIN 3 Kota Padang}

Pengawas Madrasah merupakan Pegawai Negeri Sipil yang di tunjuk oleh Kementerian Agama diberi wewenang untuk melaksanakan pembinaan dan penilaian dari segi teknis pendidikan dan administrasi pada satuan pendidikan. Pengawas bagian penting dari madrasah, ia memiliki pekerjaan serius dalam mengembangkan madrasah yakni membentuk lingkungan madrasah yang kondusif. Untuk mewujudkan visinya sebagai proses Character Building sebab hakekatnya pendidikan itu adalah proses menjadikan input (siswa) madrasah menjadi manusia yang berpotensi dengan berbasis akhlak yang baik, menciptakan lingkungan yang agamais dan relegius. Keberhasilan pendidikan tidak hanya di pengaruhi oleh guru semata akan tetapi banyak komponen pendidikan yang terlibat dalam proses tersebut antara lain: tujuan yang hendak dicapai, pendidik, peserta didik, metode, materi, sarana dan lingkungan. Oleh karena itu, pendidik maupun peserta didik sebagai subjek pendidik di tuntut untuk dapat memanfaatkan seoptimal mungkin sarana dan prasarana yang dimiliki demi tercapainya tujuan yang di inginkan. Peran pengawas madrasah adalah menjaga dan membina guru agar tetap profesional dalam menjalankan tugasnya. Peranan pengawasan atau suvervisi meliputi: Supervisi Akademik dan Supervisi Manajerial kedua supervisi ini harus dilakukan secara teratur dan berkesinambungan oleh pengawas madrasah.

Pengawas madrasah sebagai pejabat fungsional yang diberi tugas, tanggung jawab, dan wewenang melakukan pengawasan akademik dan manajerial di madrasah. Tentunya dalam melaksanakan tugasnya tidaklah terlepas dari polemik pedidikan saat ini terutama kinerja pengawas yang sangat sensitif terhadap sorotan ataupun kritikan mengingat bahwa pengawas merupakan salah satu pihak yang juga sangat menentukan mutu pendidikan.

Hasil penelitian menunjukkan bahwa pengawas madrasah melakukan monitoring dan supervisi berdasarkan program atau rencana yang pengawas siapkan sebelum melakukan supervisi untuk lebih memudahkan pembinaan terhadap kepala madrasah dan guru. Peran pengawas sudah berjalan dengan efektif, dari informasi yang diperoleh pengawas tidak hanya sebagai seorang konsultan tetapi juga sebagai motivator dalam rangka peningkatan mutu Pendidikan madrasah.

Ketika pihak Madrasah menyiapkan dokumen dalam memenuhi standar nasional pendidikan. Sehingga diharapkan mampu memperoleh nilai yang baik di bidang monitoring serta memenuhi kategori instrumen penilaian dari pengawas yang mencakup: a) standar proses, b) standar isi, c) standar pengelolaan, d) standar sarana dan prasarana, e) standar pembiayaan, f) standar pendidik dan kependidikan, g) standar kompetensi 
2786 Implementasi Supervisi Manajerial dalam Meningkatkan Mutu Pendidikan di Madrasah Ibtidaiyah - Tan Gusli, Sufyarma Marsidin, Rifma

DOI: https://doi.org/10.31004/edukatif.v3i5.945

lulusan dan h) standar penilaian pendidikan. Dan ini memang sesuai dengan tata kelola manajemen pendidikan di madrasah secara baik menurut perundang-undangan. Pengawas akan mendukung segala kegiatan yang bertujuan untuk kemajuan pendidikan, pembelajaran dan mutu pendidikan. Dalam meningkatkan mutu pendidikan Kepala Madrasah melakukan dengan prinsip keterbukaan (transparansi), kemudian ada rasa saling tanggungjawab sesuai dengan tupoksinya (akuntabilitas), Maka, dalam hal ini peran pengawas sangat diperlukan agar prinsip ini tetap diterapkan dan dipertahankan di madrasah ini.

\section{KESIMPULAN}

Sasaran supervisi manajerial yang dilaksanakan oleh pengawas pada madrasah Ibtidaiyah telah terpenuhi sesuai standar kompetensi pengawas. Pengawas dalam melakukan supervisi manajerialtelah memperhatikan kompetensi kepala madrasah dalam mengelola manajerial. Peran pengawas madrasah adalah sangat penting, tanpa adanya supervisi manajerial yang dilaksanakan oleh pengawas di madrasah ibtidaiyah maka madrasah tidak akan mampu mengembangkan madrasahnya. Pengawas bukan hanya sekedar seorang konsultas tetapi juga adalah sebagai motivator dalam rangka meningkatkan mutu pendidkan di madrasah ibtidaiyah.

\section{UCAPAN TERIMA KASIH}

Terima kasih saya sampaikan kepada isteri tercinta, ananda, dosen pembimbing, dan sahabat-sahabat mahasiswa S3 Administrasi Publik yang memberikan saran dan masukan terhadap tulisan. Sungguh tak ada gading yang tak retak, tulisan ini belumlah sempurna masih banyak kekurangan karena memang harus diakui keterbatasan referensi yang penulis miliki.

\section{DAFTAR PUSTAKA}

Aedi, N. (2014). Pengawasan Pendidikan: Tinjauan Teori Dan Praktik. Rajawali Press.

Burhanuddin, Dkk. 2007. Supervisi Pendidikan Dan Pengajaran-Konsep, Pendekatan Dan Penerapanpembinaan Profesional. Malang: Fakultas Ilmu Pendidikan Universitas Negeri Malang.

Darwin Dan Irsan, 2012, Penjamin Mutu Pendidikan Dan Pengawasan, Medan: Unimed Press

Depdiknas. (2009). Modul Metode Dan Teknik Supervisi. Direktorat Tenaga Kependidikan , Direktorat Jenderal Peningkatan Mutu Pendidik Dan Tenaga Kependidikan.

Dharma, S. (2002). Paradigma Baru: Manajemen Sumber Daya Manusia. Amara Books.

E. Mulyasa. (2011). Memahami Dan Memaknai Pendidikan Karakter. Nusantara Education Review, Vol 5 No I(Vol 5 No 1 (2011): Januari-Juni 2011). Http://Ojs.Spsuninus.Ac.Id/Index.Php/Ner/Article/View/17

Elfira, H. (2017). Peran Pengawas Madrasah Dalam Melaksanakan Supervisi Akademik Dan Supervisi Manajerial Untuk Membina Profesionalitas Pendidik Di MAN Yogyakarta 1. Universitas Islam Indonesia. Http://Hdl.Handle.Net/123456789/12131

Fatah Syukur. (2011). Manajemen Pendidikan Berbasis Pada Madrasah. Pustaka Rizki Putra.

Kependidikan, D. T. (2009). Panduan Pelaksanaan Tugas Pengawas Sekolah/Madrasah.

M. Prawiro. (2018). Pengertian Storyboard: Fungsi, Manfaat, Tujuan, Dan Cara Membuatnya.

Muktar, Iskandar, 2009, Orientasi Baru Supervisi Pendidikan, Jakarta: Gaung Persada Press

Mulyasa, E, 2011, Manajemen \& Kepemimpinan Kepala Sekolah, Jakarta: Bumi Aksara 
2787 Implementasi Supervisi Manajerial dalam Meningkatkan Mutu Pendidikan di Madrasah Ibtidaiyah - Tan Gusli, Sufyarma Marsidin, Rifma

DOI: https://doi.org/10.31004/edukatif.v3i5.945

Nuh, Mohammad. 2013. “Kurikulum 2013” (Http://Kemdikbud.Go.Id/Kemdikbud/Artikel-MendikbudKurikulum2013). Diakses Pada Tanggal 24 September 2015

Peraturan Pemerintah Pendidikan Dan Kebudayaan Republik Indonesia No. 81.A Tentang Implementasi Kurikulum

Peraturan Menteri Pendidikan Kebudayaan Republik Indonesia No. 12 Tahun 2007 Tentang Standar Kompetensi Pengawas Madrasah/Madrasah

Satori, Djam'an. 2016. Pengawasan Dan Penjaminan Mutu Pendidikan. Alfabeta: Bandung

Sudjana Dkk, Nana. 2011. Buku Kerja Pengawas Sekolah. Jakarta: Kemendiknas.

Sudrajat, Akhmad. 2008. "Tugas Pokok Dan Fungsi Pengawas Sekolah." Dalam Http://Akhmadsudrajat.Wordpress. Com/2008/04/08/Tugas-Pokok-Fungsi-Hak-Dan-Wewenang-PengawasSekolahsatuan-Pendidikan/.

Undang-Undang Nomor 20 Tahun 2003 Tentang Sistem Pendidikan Nasional

ZULbatri NASIR, 2011, MAJALAH PENUNTUn AMALbHAKTI, PADANG: KEMENTRIAN AGAMA SumbaR 